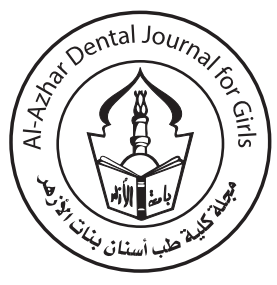

\title{
Effect of XP-endo Finisher on Microbial Root Canal Flora After Using Single-File or Multiple-File Rotary Systems
}

\author{
Hebatallah A. Fath-allah ${ }^{1^{*}}$, Wael H. Kamel ${ }^{2}$, Mohsen N. EI Din ${ }^{3}$
}

Codex : 61/20.10

azhardentj@azhar.edu.eg

http://adjg.journals.ekb.eg

DOI: 10.21608/adjg.2020.7725.1097

Restorative Dentistry

(Removable Prosthodontics, Fixed

Prosthodontics, Endodontics, Dental Biomaterials, Operative Dentistry)

\section{KEYWORDS}

XP-endo Finisher,

microbial flora,

instrumentation

\begin{abstract}
Purpose: This In vivo study was directed to compare and evaluate the bacterial count before and after preparing the root canals with the following variables: Single and multiple file rotary systems and Finishing after preparation with and without Xp-endo finisher. Methods: A total of 40 patient requiring endodontic treatment of both sexes were enrolled for this study from the dental hospital of Nahda University in BaniSuef. Patients were fully informed about the study`s procedures, benefits and risks. They signed an informed consent. Patients were divided into two groups according to the rotary system used ProTaper universal and one shape $(n=20)$ and after preparation each group was subdivided into two subgroups according to the usage of XP-endo finisher or not $(n=10)$. Irrigation during instrumentation performed with sterile saline. Three bacteriological samples were taken using paper points: S1: before mechanical preparation, S2: immediately after mechanical preparation, S3: 7 days after mechanical preparation before obturation. The plates were incubated for 24 hours at $37^{\circ} \mathrm{c}$. The number of colony forming units (CFUs) was counted and calculated. Results: The bacterial count was reduced significantly in experimentation groups at S2 and S3 compared to S1. However, S3 compared to S2 show bacterial regrowth in the canal. For ProTaper groups there was a statistically significant difference between (XP) and (Without XP) groups. And also for OneShape groups there was a statistically significant difference between (XP) and (Without XP) groups, in the bacterial reduction.
\end{abstract}

\section{INTRODUCTION}

Periradicular periodontitis has been attributed to bacteria and their byproducts. These microorganisms nourish upon pulpal connective

- Paper extracted from Doctor thesis titled "Effect of XP-endo Finisher on Microbial Root Canal Flora after Using Single-File or Multiple-File Rotary Systems“"

1. Assistant Lecturer of Endodontics, Faculty of Oral and Dental Medicine, Nahda University.

2. Professor and Head of Endodontic Department, Faculty of Dental Medicine for Girls, Al-Azhar University, Cairo, Egypt

3. Professor of Endodontics, Endodontic Department, Faculty of Dental Medicine for Girls, Al-Azhar University, Cairo, Egypt

* Corresponding author email: huby198@gmail.com 
tissue, salivary and serum proteins from the periradicular tissues. Root canal disinfectant should access and eliminate microbes from all parts of the system $^{(1)}$. Bacterial elimination is an imperative phase in endodontic treatment.

The root canals are shaped by using a set of instruments with different tip diameters. The ProTaper Universal system, consist of nickel-titanium (NiTi) files used in successive order in continuously rotating motion, this system has become the new 'Gold standard' in endodontics (2). The goal of any instrumentation systems is reducing working time, minimizing operator stress, and working with less files. The One Shape ${ }^{\circledR}$ single-file system uses the continuous rotation action. Variability in the cross section allows for 3 cutting angles in apical $2 \mathrm{~mm}, 2$ cutting angles middle and closest to shank ${ }^{(3)}$. But the complex nature of root canal anatomy which contain webs, isthmuses, anastomoses, fins, and other irregularities complicates complete debridement ${ }^{(4)}$. The XP-endo Finisher is an ISO 25/.00 instrument recently introduced to improve the effect of irrigation by irrigant activation. XPF produced using the NiTi MaxWire alloy. The file in ( $M$ phase) is unbent, but on exposure to body temperature changes to (A phase) and changes to spoon-shape with a length of $10 \mathrm{~mm}$ and a $1.5 \mathrm{~mm}$ depth achieved by molecular memory ${ }^{(5)}$. The special design of the XPF contributes to the cleansing of prepared root canals of size 25 even in cases with complex morphologies and areas difficult to reach by rotary instruments ${ }^{(6)}$, but the effectiveness of the XPF file in terms of bacterial reduction is a question that needs to be answered.

\section{MATERIALS AND METHODS}

\section{Case selection:}

A total of 40 patients requiring endodontic treatment of both sexes were enrolled for this study from the dental hospital of Nahda University in BaniSuef. Patients were fully informed about the study`s procedures, benefits and risks. All patients were informed in details about the nature of investi- gation and purpose of the study. They agreed to take part in it, signed on an informed consent form, and REC approval was obtained. All reasonable steps to protect the security of the personal information and privacy of the patient protected health information were being taken. Inclusion criteria were as follows: The aim and the requirements of the study are freely accepted, treatment is limited to patients medically free from any systemic diseases, patients between the age group of 20 and 40 years old, absence of preoperative pain, necrotic cases only, presence of periapical radiolucency 1-5 $\mathrm{mm}$ in diameter and no antibiotics in the past three months. Exclusion criteria includes the following: Teeth with symptomatic irreversible pulpitis, teeth with open apices, consumption of any type of antibiotics in the past three months, systemic diseases, pregnant and lactating female.

\section{Clinical and radiographic evaluation:}

A complete history was obtained and clinical examination was conducted on each of the selected case according to diagnostic sheet. A preoperative periapical radiograph had been taken for each selected tooth using digital X- ray system PSPIX ${ }^{2}$ Acteon Imaging manufactured by SOPRO and de Gotzen, France ${ }^{2}$ to evaluate the periapical radiolucency.

\section{Grouping of the patients:}

Patients were randomly divided into two main groups, 20 cases for each, according to the type of the rotary system that used. Group I: using ProTaper Universal rotary system ${ }^{2}$ Dentsply Maillefer, Ballaigues, Switzerland ${ }^{2}$. Group II: using OneShape single file system ${ }^{2}$ Micro Méga, Besançon, France 2 . Each main group was divided into two subgroups, 10 teeth for each, according to the usage of XP-endo Finisher ${ }^{2}$ FKG Dentaire SA, Switzerland ${ }^{2}$ or not.

\section{Treatment protocol and Microbiological sampling:}

Lidocaine topical anesthesia was used at the site of injection. Local anesthesia was delivered to the patients, the teeth were put into isolation with a 
rubber dam, 30\% hydrogen peroxide was used to disinfect the crown followed by $2.6 \%$ sodium hypochlorite $(\mathrm{NaOCl})$ for the $30 \mathrm{sec}$ and then inactivated with $5.0 \%$ sodium thiosulfate solution. a swab sample from the crown surface was taken to check the sterility of the crown. An access cavity preparation was made using manual irrigation with sterile saline solution in 2 stages. The first stage included removal of carious lesions and old restorations using sterile round bur mounted in high speed hand piece. In the second stage, before re-entering the pulp chamber, disinfection protocol was repeated, followed by deroofing and flaring of the access cavity using Endo Z bur ${ }^{2}$ Dentsply Maillefer, Ballaigues, Switzerland ${ }^{2}$.

Sampling: Immediately before chemomechanical preparation, an initial sample (S1) was taken from the root canal to serve as the standard baseline. Sterile saline solution $(0.9 \% \mathrm{NaCl})$ was injected in the pulp chamber without overflowing, and a small hand file \#202 Dentsply Maillefer, Ballaigues, Switzerland ${ }^{2}$ was used in circumferential strokes to break away content of canal wall into solution. Sterile paper points of size \# 20 were gently placed $1 \mathrm{~mm}$ short of the root apex taking care not to touch the access cavity walls. Fluid in the canal was soaked-up by leaving each paper point in the canal for 1 minute. The sampling procedure was rerun for the following 3 paper points that were put in a sterile tube containing $1 \mathrm{~mL}$ brain heart infusion broth for microbial cultivation (the first sample $\mathrm{S} 1)$. After irrigation with $1 \mathrm{~mL}$ sterile saline $(0.9 \%)$ the working length (WL) was settled $1 \mathrm{~mm}$ less than the length of apical foramen by using an electronic apex locator ${ }^{2}$ Apex ID ${ }^{\text {тм }}$ digital apex locator, SybronEndo, Orange, CA, USA ${ }^{2}$. A patency file of size 20 was used to enlarge the canal. Irrigation during instrumentation which delivered using plastic syringe with side vented needle ${ }^{2}$ Endo-Top, CERKAMED medical company ${ }^{2}$ with sterile saline $(0.9 \%)$. Root canals in each group were instrumented with tested instruments (ProTaper Universal rotary Ni Ti and OneShape rotary Ni Ti instrument). These instruments were mounted in gear reduction handpiece that was powered by controlled electric motor which set in rotation motion speed and torque according to manufacture instruction .Root canals were thoroughly irrigated with $2 \mathrm{ml}$ of $0.9 \%$ saline solution using Endo-top side vented irrigation needle. The needle was inserted $2 \mathrm{~mm}$ shorter than the final working length without locking in the canal. In the subgroups of XPF, following instrumentation, cleaning was accomplished using saline solution $(0.9 \% \mathrm{NaCl})$ and XPF file. The XPF \#25/0 taper was removed from the blister pack and mounted in 16:1 handpiece that was powered by torque controlled electric motor at a rotational speed $800 \mathrm{rpm}$ and torque $1 \mathrm{~N} / \mathrm{cm}$. The XPF was then inserted into the root canals of tested specimens to full working length while not rotating. Following this the instrument was rotated in the canal for one minute using slow and gentle in and out movements in the canal. Then the XPF file was retracted from the canal while still in rotation. Irrigation was done accomplished with saline solution using 30 gauge Endo-Top needle. After instrumentation, sampling procedure was performed again (S2) as described for (S1) with paper points \# 40. Another sample was obtained after one week before obturation (S3). The access cavity was closed using Cavit TM "3M ESPE, United State« as a temporary restoration between the visits. No intra canal medication was inserted inside the canal in between the visits. After S3 and before obturation Final flush was performed using $1 \mathrm{ml}$ 17\% EDTA solution for one minute , $5 \mathrm{ml} 2.6 \% \mathrm{NaOCl}$ for one minute and then with $5 \mathrm{~mL}$ distilled water.

Cultivations: Each tube containing the paper points was subjected to Vortex for one minute to allow the bacteria to fall down in the transporting medium. Ten-fold serial dilutions were made for each sample, so that each sample had three dilutions "1/10, 1/100 and 1/1000" (Figure 16). Next, $50 \mu \mathrm{L}$ were taken from each dilution and inoculated over the surface of sheep blood agar plates and spread over the plates using glass rods. The plates were incubated for 24 hours at $37^{\circ} \mathrm{c}$. The number of colony forming units (CFUs) was counted and calculated. 


\section{RESULTS}

For ProTaper groups: There was a statistically significant difference between (With XP) and (Without XP) subgroups where $(p=0.040)$. The highest bacterial reduction was found in (With XP) group ${ }^{297.59 \%} \%^{2}$ while the least bacterial reduction was found in (Without XP) group $273.23 \%{ }^{2}$.

For OneShape groups: There was a statistically significant difference between (With XP) and (Without XP) subgroups where $(\mathrm{p}=0.043)$. The highest bacterial reduction was found in (With XP) group $295.57 \%$, while the least bacterial reduction was found in (Without XP) group $272.99 \%{ }^{2}$. As shown in table (1).

In the subgroups with XP-endo Finisher: There was no statistically significant difference between (ProTaper) and (OneShape) groups where $(p=0.999)$. The highest bacterial reduction was found in (ProTaper) group, while the least bacterial reduction was found in (OneShape) group.

In the subgroups without XP-endo finisher There was no statistically significant difference between (ProTaper) and (OneShape) groups where $(p=0.993)$. The highest bacterial reduction was found in (ProTaper) group, while the least bacterial reduction was found in (OneShape) group.
Relation between subgroups in bacterial growth between (S3 and S2):

For ProTaper groups: There was a statistically significant difference between (With XP) and (Without XP) groups where $(p<0.001)$. The highest bacterial growth was found in (Without XP) group, while the least bacterial growth was found in (With $\mathrm{XP)}$ group.

For One Shape groups: There was a statistically significant difference between (With XP) and (Without XP) groups where $(p<0.001)$. The highest bacterial growth was found in (Without XP) group, while the least bacterial growth was found in (With $\mathrm{XP}$ ) group as shown in figure (1).

Relation between groups in bacterial growth between (S3 and S2):

For With XP groups: There was no statistically significant difference between (ProTaper) and (OneShape) groups where $(p=0.823)$. However the highest bacterial growth was found in (OneShape) group, while the least bacterial growth was found in (Protaper) group.

For Without XP groups: There was no statistically significant difference between (ProTaper) and (OneShape) groups where $(p=0.691)$. The highest bacterial growth was found in (OneShape) group, while the least bacterial growth was found in (ProTaper) group.

Table (1): The mean, standard deviation (SD) values of bacterial reduction (S1-S2) of different groups.

\begin{tabular}{|c|c|c|c|c|c|c|c|}
\hline \multirow{3}{*}{ Variables } & \multicolumn{7}{|c|}{ Bacterial reduction (S1-S2) } \\
\hline & \multicolumn{3}{|c|}{ ProTaper } & \multicolumn{3}{|c|}{ OneShape } & \multirow[t]{2}{*}{ P-value } \\
\hline & Mean & SD & $\%$ & Mean & SD & $\%$ & \\
\hline With XP & $5.51^{\mathrm{aA}}$ & 0.53 & 97.59 & $5.51^{\mathrm{aA}}$ & 0.54 & 95.57 & $0.999 \mathrm{~ns}$ \\
\hline Without XP & $4.86^{\mathrm{bA}}$ & 0.27 & 73.23 & $4.86^{\mathrm{bA}}$ & 0.27 & 72.99 & $0.993 n s$ \\
\hline p-value & \multicolumn{3}{|c|}{$0.040 *$} & \multicolumn{3}{|c|}{$0.043 *$} & \\
\hline
\end{tabular}

Means with different lower case letters in the same column indicate statistically significance difference. Means with different upper case letters in the same row indicate statistically significance difference *; significant $(p<0.05)$ $n s$; non-significant $(p>0.05)$ 


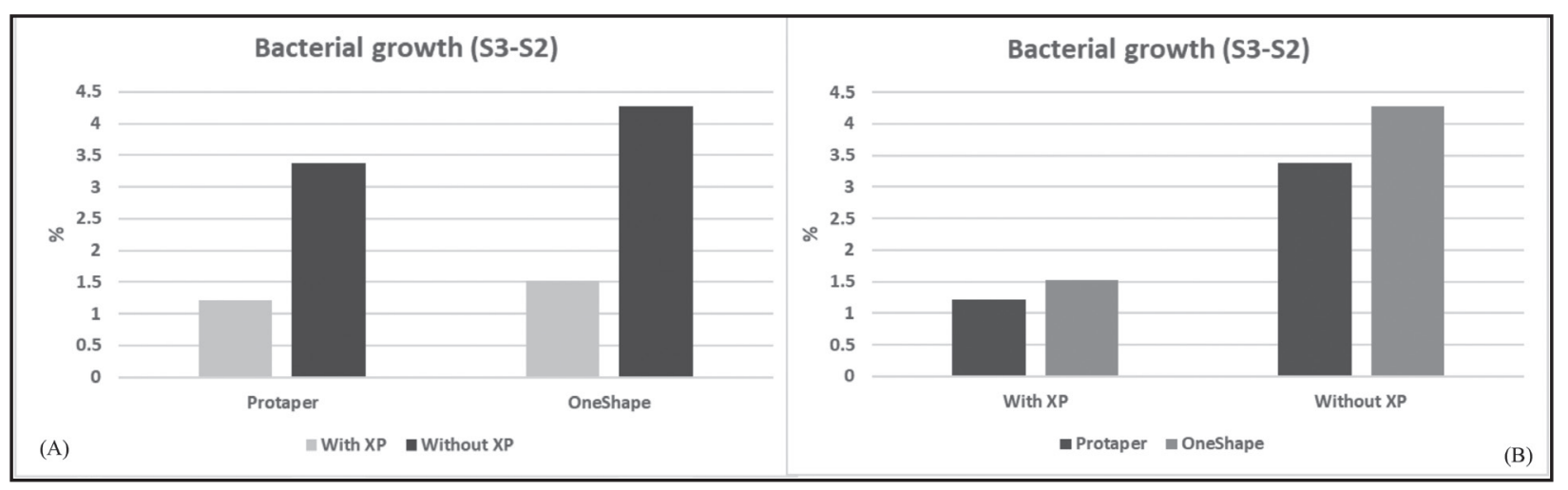

Figure (1) Bar chart representing bacterial growth (S3-S2) in different groups

\section{DISCUSSION}

Pulp and periapical diseases are mainly contributed to bacteria and their byproducts. the main aim of endodontic therapy is complete eradication of bacteria, their byproducts, and removal of infected pulp tissue to allow healing of periradicular tissue and refine prognosis of endodontic treatment by instrumentation, irrigation, and medication. ${ }^{(5)}$

Necrotic pulp and infected dentin play an important role in producing apical lesions. The aim of endodontic treatment is to reduce intracanal bacterial count and their byproducts, because the presence of bacteria is the main cause of failure. Different studies focused on this concept ${ }^{(7,8,9)}$.

Forty patients in need of endodontic treatment were included in the present study, age between 2040 years old and free of medical problems. Medical/ dental history was obtained from each patient. Any patient who received antibiotic drugs in the last 3 months or had any systematic disease were excluded from the study. All the selected teeth were single-root single-canal with $1^{\text {ry }}$ endodontic infection, and absenteeism of periodontal pockets more than 4 $\mathrm{mm}$. also with periapical radiolucency ranging from 1-5 $\mathrm{mm}$ in diameter. Patients showed no spontaneous pain. Failure to isolate tooth by rubber dam got it excluded ${ }^{(10,11)}$. Strict aseptic environment was ensured through proper infection control protocol with $30 \%$ hydrogen peroxide for 40 seconds followed by
$2.5 \%$ sodium hypochlorite $(\mathrm{NaOCl})$ for the same period of time and then inactivated with $5 \%$ sodium thiosulfate, as recommended by previous studies ${ }^{(13)}$.

The bacterial sampling process was done three times throughout the study; the initial sample (S1) after access cavity preparation and before instrumentation to count the number of bacteria inside the canal to compare it with that found after instrumentation (S2) ${ }^{(3,7,14,15)}$. A third sampling was performed to find out the bacterial count after 7 days following instrumentation (S3) to verify bacterial growth in the root canal between appointments ${ }^{(15-17)}$.

The bacterial sampling were done by inserting a three successive absorbent paper points inside the canal and leaving each paper point for 1 minute to allow it to completely saturated with the solution inside the canal ${ }^{(7,16)}$ and then transferred to tubes containing $1 \mathrm{ml}$ of brain-heart infusion broth (BHI), then the tubes were vortexed for $1 \mathrm{~min}$ to allow evacuation of bacterial load off paper point ${ }^{(18,19)}$.

The use of paper point for bacterial sampling is a simple method and can be performed both invitro and invivo but is limited to root canal which can be sampled, while microbes located in dentinal tubules cannot be loaded ${ }^{(20,21)}$.

Furthermore serial dilution of a sample were used, serial dilution is mandatory to separate bacteria into recognizable C.F.U. (colony forming units), dilute the numbers to $50-300$ per plate making them 
countable and differentiate colony types for identification of individual species ${ }^{(8,14)}$.

There are two ways of bacterial identification; plate culture and molecular polymerase chain reaction methods; in the present study, the plate culture method was used as it is the frequent method in bacterial reduction studies, which allows the quantification of micro-organisms in root canal, and has the advantage of allowing all cells in the sample to flouish, then cultured and thus identified but the culture technique has limited value because low numbers of bacteria that cannot live in culture go undetected. However, our results show that large numbers of bacteria can be detected using this method ${ }^{(3,16)}$.

The molecular methods are the most sensitive bacterial detection tests; however in another study similar results were obtained using both techniques ${ }^{(22)}$.

Therefore, the objective of this study was to assess the efficacy of the XPF file on microbial flora after biomechanical instrumentation using ProTaper universal and OneShape in comparison to not using it.

XP-endo finisher is a NiTi file based on the shape-memory principles of the alloy, with a core size of 25 and non-tapered; its design follows any root canal anatomy and cleans complex morphologies and otherwise unreachable areas ${ }^{(6,23)}$.

The XP-endo Finisher changes shape according to temperature. At room temperature, is in its martensitic phase (M-phase), and the file is erect. At $37^{\circ} \mathrm{c}$, transform into austenitic phase (A-phase) and attains a spoon shape $1.5 \mathrm{~mm}$ deep and $10 \mathrm{~mm}$ long. When rotating, the unique shape allows the file to clean unreachable areas, without reshaping the original canal anatomy, or damaging dentine. Although auspicious, only few reports analyzed its effectiveness ${ }^{(5,6,23,29)}$.

In the present study, without XP-endo Finisher the amount of bacterial reduction between ProTaper group and OneShape group were $73.23 \%$ and $72.99 \%$ respectively. With insignificant difference between them. These results are similar to other studies ${ }^{(7)}$ but with bacterial reduction for ProTaper and OneShape $100 \%$ and $97.92 \%$ respectively and this may be due the difference in the type of the irrigant solution. In this study all specimens were irrigated with $5.25 \% \mathrm{NaOCl}$ while in this study all the specimens were irrigated with $0.9 \%$ sterile saline.

With XP-endo Finisher, there was no statistically significant difference between (ProTaper) and (OneShape) groups in the bacterial reduction with $97.59 \%$ and $95.57 \%$ respectively, The highest bacterial reduction was found in (ProTaper) group, while the least bacterial reduction was found in (OneShape) group with and without XP-endo Finisher may be due to greater taper of ProTaper files.

For ProTaper groups there was a statistically significant difference between (With XP) and (Without XP) groups $97.59 \%$ and $73.23 \%$ respectively where $(p=0.040)$. And also for OneShape groups there was a statistically significant difference between (With XP) and (Without XP) groups $95.57 \%$ and $72.99 \%$ respectively where $(p=0.043)$. canal walls may remain unaffected by instrumentation due to insufficient enlarging of the canal by available instrument system. Such a problem is recurrent with systems that come with predetermined sizes ${ }^{(2)}$.

So the use of XP-endo Finisher accesses and cleans areas unreachable by other instruments, without canal shape alteration and no damage to the dentinal wall ${ }^{(26)}$.

The third sampling after 7 days (S3) was used to check bacterial regrowth between appointments. The bacterial counts exhibited significant reduction in study groups at both S2 and S3 compared with $\mathrm{S} 1$. However, the S3 compared to S2 show bacterial regrowth in the canal of statistical significance. Coronal bacterial leakage may also be the cause for bacterial growth in the canal after 7 days as we used temporary restoration between appointments not a semi-permanent restoration and we left the canal empty without any intra canal medications. 
According to similar study ${ }^{(22)}$, the $\mathrm{S} 3$ samples show significantly higher bacterial counts than the samples tested immediately after instrumentation this agreed with our present study. On the other hand this finding are opposite to the results found in another study ${ }^{(15)}$, all of the taxa found in S2 samples were eliminated after 7-days because an intracanal medication with the paste of $\mathrm{Ca}(\mathrm{OH}) 2$ in $0.12 \%$ CHX gel used between the appointment.

\section{CONCLUSION}

Within the limitations of the present study, XPendo Finisher is a promising instrument that exhibited antibacterial effectiveness with significant reduction in the bacterial count after mechanical preparation. Multiple files system (ProTaper) is more effective in bacterial reduction than single file system (OneShape).Multiple visit treatment enhance bacterial count inside root canal after mechanical instrumentation.

\section{REFERENCES}

1. Coldero LG, McHugh S, MacKenzie D, Saunders WP. Reduction in intracanal bacteria during root canal preparation with and without apical enlargement. Int Endod J. 2002; 35:437-446.

2. Neves M a. S, Provenzano JC, Rôças IN, Siqueira JF. Clinical Antibacterial Effectiveness of Root Canal Preparation with Reciprocating Single-instrument or Continuously Rotating Multi-instrument Systems. J Endod. 2016; 42:25-29.

3. Nabeshima CK, Caballero-Flores H, Cai S, Aranguren J, Borges Britto ML, de Lima Machado ME. Bacterial Removal Promoted by 2 Single-file Systems: Wave One and One Shape. J Endod. 2014; 40:1995-1998.

4. Carver K, Nusstein J, Reader a, Beck M. In Vivo Antibacterial Efficacy of Ultrasound after Hand and Rotary Instrumentation in Human Mandibular Molars. J Endod. 2007; 33:1038-1043.

5. Bao P, Shen Y, Lin J, Haapasalo M. In Vitro Efficacy of XP-endo Finisher with 2 Different Protocols on Biofilm Removal from Apical Root Canals. J Endod. 2016:1-5.

6. Wigler R, Dvir R, Weisman A, Matalon S, Kfir A. Efficacy of XP-endo finisher files in the removal of calcium hydrox- ide paste from artificial standardized grooves in the apical third of oval root canals. Int Endod J. 2017; 50:700-705.

7. Vossoghi M, Vossoghi M, Shahriari S, Faramarzi F, Yousefi R. Efficacy of a Novel Rotary System in Reduction of Intracanal Bacteria : An in Vitro Study. Iran Endod J. 2016; 11:219-222.

8. Gorduysus M, Nagas E, Torun OY, Gorduysus O. A comparison of three rotary systems and hand instrumentation technique for the elimination of Enterococcus faecalis from the root canal. Aust Endod J. 2011; 37:128-133.

9. Sakamoto M, Jr SJF. Bacterial reduction and persistence after endodontic treatment procedures. Oral Microbiol Immunol. 2007; 22:19-23.

10. Xavier ACC, Martinho FC, Chung A, Oliveira LD, Jorge OC, Valera C. One-Visit Versus Two-Visit Root Canal Treatment: Effectiveness in the Removal of Endotoxins and Cultivable Bacteria. J Endod. 2013; 39:959-964.

11. Martinho FC, Chiesa WMM, Marinho ACS, et al. Clinical Investigation of the Efficacy of Chemomechanical Preparation with Rotary Nickel-Titanium Files for Removal of Endotoxin from Primarily Infected Root Canals. J Endod. 2010; 36:1766-1769.

12. Martinho FC, Gomes BPFA. Quantification of Endotoxins and Cultivable Bacteria in Root Canal Infection before and after Chemomechanical Preparation with $2.5 \%$ Sodium Hypochlorite. J Endod. 2008; 34:268-272.

13. Gomes BPFA, Martinho FC, Vianna ME. Chlorhexidine Gel on Oral Bacterial Lipopolysaccharide Reduction from Primarily Infected Root Canals. J Endod. 2009; 35:13501353.

14. Rai K, Goel M, Sachdeva GS, Verma S, Mandhotra P. Comparative Evaluation of Three Rotary File Systems regarding Root Canal Disinfection : An In- Vitro Study. Int J Oral Heal Med Res. 2016; 3:54-57.

15. Siqueira JF Jr, Paiva SSM, Rocas IN. Reduction in the Cultivable Bacterial Populations in Infected Root Canals by a Chlorhexidine-based Antimicrobial Protocol. J Endod. 2007; 33:541-547.

16. Machado MEL, Nabeshima CK, Leonardo MFP, Reis FAS, Britto MLB, Cai S. Influence of reciprocating singlefile and rotary instrumentation on bacterial reduction on infected root canals. Int Endod J. 2013; 46:1083-1087.

17. Machado MEL, Nabeshima CK, Caballero-Flores H, et al. Instrument design may influence bacterial reduction during root canal preparation. Braz Dent J. 2017; 28:587-591. 
18. Siqueira JF, Rôças IN, Santos SRLD, Lima KC, Magalhães $\mathrm{FaC}$, de Uzeda M. Efficacy of instrumentation techniques and irrigation regimens in reducing the bacterial population within root canals. J Endod. 2002; 28:181-184.

19. Maria L, Nóbrega M, Gadê-neto CR, Dametto FR, Sarmento CFDM, Carvalho RA De. Ultrasonic irrigation in the removal of smear layer and Enterococcus faecalis from root canals. Braz J Oral Sci. 2011; 10:221-225.

20. Chu FCS, Tsang CSP, Chow TW, Samaranayake LP. Identification of cultivable microorganisms from primary endodontic infections with exposed and unexposed pulp space. J Endod. 2005; 31:424-429.

21. Matuso T, Shirakami T, Ozaki K, Nakanishi T, Yumoto J, Ebisu S. An immunohisto- logical study of the localization of bacteria invading root pulpal walls of teeth with periapical lesions. J Endod 2003; 194-200.

22. Alves FRF, Rôças IN, Almeida BM, Neves MAS, Zoffoli J, Siqueira JF. Quantitative molecular and culture analyses of bacterial elimination in oval-shaped root canals by a single-file instrumentation technique. Int Endod J. 2012; 45:871-877.

23. Leoni GB, Versiani MA, Silva-Sousa YT, Bruniera JFB, Pécora JD, Sousa-Neto MD. Ex vivo evaluation of four final irrigation protocols on the removal of hard-tissue debris from the mesial root canal system of mandibular first molars. Int Endod J. 2017; 50:398-406.
24. Elnaghy AM, Mandorah A, Shaymaa bullet, Elsaka E. Effectiveness of XP-endo Finisher, EndoActivator, and File agitation on debris and smear layer removal in curved root canals: a comparative study. Odontology. 2016; 105:178-183.

25. Uygun $A D$, Gündoğdu EC, Arslan H, Ersoy İ. Efficacy of XP-endo finisher and TRUShape 3D conforming file compared to conventional and ultrasonic irrigation in removing calcium hydroxide. Aust Endod J. 2016:3-7.

26. Silva EJNL, Belladonna FG, Zuolo AS, et al. Effectiveness of XP-endo Finisher and XP-endo Finisher R in removing root filling remnants: A micro-CT study. Int Endod J. 2017; 51:86-91

27. Alves FR, Andrade-Junior CV, Marceliano-Alves MF et al. Adjunctive steps for disinfection of the mandibu- lar molar root canal system: a correlative bacteriologic, microcomputed tomography, and cryopulverization approach. J Endod. 2016; 42, 1667-1672.

28. Azim AA, Aksel H, Zhuang T, Mashtare T, Babu JP, Huang GT. Efficacy of 4 irrigation protocols in killing bacteria colonized in dentinal tubules examined by a novel confocal laser scanning microscope analysis. J Endod. 2016; 42, 928-934.

29. Keskin C, Evren Sariyilmaz and OS. Efficacy of XPendo Finisher File in Removing Calcium Hydroxide from Simulated Internal Resorption Cavity. J Endod. 2017; 43:126-130. 